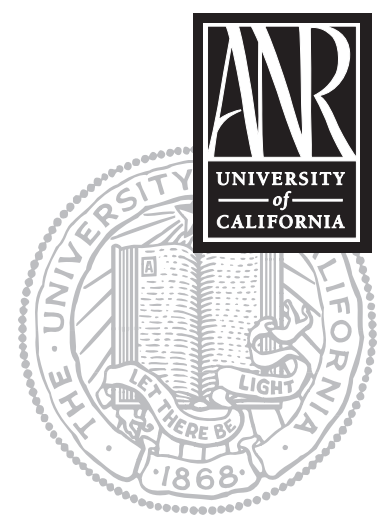

UNIVERSITY OF CALIFORNIA

Division of Agriculture and Natural Resources http://anrcatalog.ucdavis.edu

\title{
NUTRITION AND HEALTH INFO SHEET Vegetarian Diets
}

EMILY R. CENA, Postdoctoral Scholar, Department of Nutrition, University of California, Davis; KARRIE HENEMAN, Assistant Project Scientist, Department of Nutrition, University of California, Davis; SHERI ZIDENBERG-CHERR, UC Cooperative Extension Nutrition Science Specialist, Department of Nutrition, University of California, Davis

\section{What is a vegetarian diet?}

A vegetarian diet is one that consists primarily of plant foods, but may include eggs (called ovo-vegetarian), dairy products (called lacto-vegetarian), or both eggs and dairy products (called lacto-ovo-vegetarian). The vegan, or total vegetarian, diet completely excludes meat, fish, poultry, eggs, and dairy products (1). Of course, there are many variations on these themes; some people follow a semi-vegetarian diet which excludes red meat but includes small amounts of fish and poultry (2). Whether vegetarian or containing small amounts of meat, plant-based diets that include ample fruits, vegetables, legumes, and whole grains can help reduce the risk of chronic disease by minimizing the intake of saturated fat and cholesterol, while providing dietary fiber and phytochemicals found only in plant sources.

\section{Are vegetarians at risk of being deficient in certain nutrients?}

A well-planned vegetarian diet can provide sufficient amounts of the essential nutrients. However, as with any diet, the more restrictive a vegetarian diet is, the higher the risk for nutrient deficiencies. Thus, for example, the most extreme vegans who eliminate all animal foods from their diet need to plan their meals carefully by consuming a wide variety of nutrient-dense foods. This is to ensure that they consume enough of the following nutrients, which have been found to be low in non-meatbased diets (3):

\section{Protein}

Vegetarian diets can supply adequate protein, provided that rich protein sources are included, such as beans and nuts, and higher-protein grains such as quinoa. Animal sources of protein are more easily digested than plant sources, so a vegan diet may have higher protein requirements than a diet that includes eggs or dairy products.

\section{Iron}

Adequate iron intake depends on both the amount of dietary iron consumed and the amount available for absorption. Iron absorption rates vary depending on physiological need and on the presence of other dietary components. These components can either reduce iron absorption (as with phytates and oxalates) or enhance iron absorption (as with vitamin C). Non-heme iron, the form of iron found in plants, is more sensitive to these influences than the heme iron found in animal products. Dried beans, fortified breads and cereals, spinach, chard, blackstrap molasses, bulgur, and dried fruit are good sources of non-heme iron. To improve iron absorption from these and other ironrich plant foods, consume vitamin C-rich foods at the same meal.

\section{Calcium}

For vegetarians who include dairy products in their diets, meeting calcium requirements is the same as for omnivores (individuals who eat plant and animal foods). Vegetarians and vegans who choose to avoid dairy products should take special care to consume adequate amounts of calcium from nondairy sources, such as collard 
greens, spinach, almonds, soybeans, and turnip greens, in addition to calcium-fortified orange juice, cereal, soy milk, and tofu. Unfortunately, substances found in some vegetables, such as oxalic acid, may reduce the body's absorption of calcium, so individuals choosing to avoid dairy products should be sure to consume a variety of calcium-rich foods. (A list of calcium-rich foods is included in table 1.)

Zinc

Good plant sources of zinc include whole grains, nuts, and legumes; however, the zinc found in plant foods is not as well absorbed as the zinc in meat because phytates in plants bind to zinc. Vegetarian children, especially vegans, are more vulnerable to zinc deficiency than are adults, presumably because of the high zinc levels required for growth. Ample intake of legumes and whole grains may provide adequate zinc, but vegan children (and adults) should be aware of the possibility of zinc deficiency. Compared to vegans, vegetarians who eat eggs or dairy products are less likely to be deficient in this mineral.

Vitamin $B_{12}$

Because vitamin $B_{12}$ is found in all animal products, a dietary pattern that includes foods such as dairy products or eggs is likely to be sufficient in vitamin $\mathrm{B}_{12}$. Plants do not provide active vitamin $B_{12}$, making it essential for vegans to include a reliable source of this vitamin in their diets. Research has shown an association in vegetarians between low levels of vitamin $B_{12}$ and elevated levels of homocysteine, a marker of cardiovascular disease, suggesting that vegetarians should be careful to consume adequate amounts of this nutrient as well (4). Elderly vegetarians are especially prone to vitamin $\mathrm{B}_{12}$ deficiency, because the body's ability to absorb this vitamin tends to decline with age. The active form of the vitamin (cyanocobalamin) is found in vitamin supplements and fortified foods, such as some commercial breakfast cereals, soy beverages, and certain brands of nutritional yeast. Be sure to check the label to determine whether these items contain vitamin $B_{12}$. Spirulina, seaweed, tempeh, and other fermented foods are not reliable sources of the vitamin, as the form of $\mathrm{B}_{12}$ in these foods may be inactive.

\section{Vitamin D}

This vitamin is synthesized by the body upon exposure to sunlight, but many Americans today do not meet their vitamin D requirements with sun exposure alone. Food sources of vitamin D include vitamin D-fortified dairy products, egg yolks, liver, and fatty fish. Vegans are, therefore, particularly susceptible to vitamin D deficiency and should take special care to consume foods fortified with vitamin D, such as some breakfast cereals and certain brands of soy milk. They may also consider taking supplements that provide calcium and the active form of vitamin D (cholecalciferol) together.

\section{Omega-3 Fatty Acids}

These essential fats can be found in both plant and animal foods (including nuts, seeds, plant oils, and fish), and their consumption has been associated with a reduced risk of cardiovascular disease. A recent study found that both vegans and vegetarians, in comparison to omnivores, may consume inadequate amounts of omega-3 fatty acids (measured by omega- 3 fatty acid levels in sphingolipids, phosphatidylcholine, phosphatidylserine, and phosphatidylethanolamine), thus suggesting a need for vegetarians to include rich sources of omega-3 fatty acids in their diets (5). The best plant sources of these fats are walnuts and ground flaxseeds (or flaxseed oil), but the type of omega-3 fatty acid in these foods (alpha linolenic acid) is not efficiently converted to the essential types found in fish, called EPA and DHA (eicosapentaenoic acid and docosahexaenoic acid). Individuals who follow a plant-based diet but include fish will likely consume sufficient EPA and DHA, but vegetarians who do not consume any fish should consider a supplement containing these two components. 


\section{How can vegetarians plan healthful meals?}

The United States Department of Agriculture (USDA) Web site, MyPyramid.gov, provides the following recommendations for planning vegetarian meals: (3)

- Build meals around protein sources that are naturally low in fat, such as beans, lentils, and rice. Avoid overloading meals with high-fat cheeses to replace the meat.

- Calcium-fortified, soy-based beverages can provide calcium in amounts similar to milk. They are usually low in fat and do not contain cholesterol.

- Many foods that typically contain meat or poultry can be made vegetarian. Eliminating the meat can increase vegetable intake and reduce saturated fat and cholesterol intake.

Vegetarians can also turn to many ethnic cuisines, such as Indian, Middle Eastern, Hispanic, and Asian, for plant-based dishes that include protein in the form of beans, nuts, and higher-protein grains.

Several vegetarian food guide pyramids have been developed and may serve as helpful tools for planning a healthy vegetarian diet. One example is shown in table 1 (6). Another example, adopted by the Mayo Clinic, is available online at http://www.mayoclinic.com/health/healthy-diet/NU00190 (7).

\section{Table 1. Vegetarian food guide pyramid for adults (6)}

\begin{tabular}{|c|c|c|c|}
\hline Food group & $\begin{array}{l}\text { Servings } \\
\text { daily }\end{array}$ & Serving size & $\begin{array}{l}\text { Calcium-rich foods } \\
\text { (8 servings/day)* }\end{array}$ \\
\hline fruits & 2 & $\begin{array}{l}1 \text { medium fruit } \\
1 / 2 \text { cup diced or cooked fruit } \\
1 / 4 \text { cup dried fruit } \\
1 / 2 \text { cup fruit juice }\end{array}$ & $\begin{array}{l}5 \text { figs } \\
1 / 2 \text { cup calcium-fortified fruit juice }\end{array}$ \\
\hline grains & 6 & $\begin{array}{l}1 \text { slice bread } \\
1 \text { oz ready-to-eat cereal ( } 1 \text { cup) } \\
1 / 2 \text { cup cooked grain or cereal }\end{array}$ & 1 oz calcium-fortified breakfast cereal \\
\hline $\begin{array}{l}\text { legumes, nuts, } \\
\text { and other } \\
\text { protein-rich } \\
\text { foods }\end{array}$ & 5 & $\begin{array}{l}1 / 2 \text { cup cooked beans, peas, or lentils } \\
1 \text { egg } \\
2 \text { Tbsp nut or seed butter } \\
1 \text { oz meat substitute } \\
1 / 4 \text { cup nuts } \\
1 / 2 \text { cup tofu or tempeh }\end{array}$ & $\begin{array}{l}1 / 4 \text { cup almonds } \\
2 \text { Tbsp almond butter or sesame tahini } \\
3 / 4 \text { oz cheese } \\
1 / 2 \text { cup cow's milk, yogurt, or calcium-fortified soymilk } \\
1 / 2 \text { cup cooked soybeans } \\
1 / 4 \text { cup soy nuts } \\
1 / 2 \text { cup tempeh or calcium-set tofu }\end{array}$ \\
\hline oils & 2 & 1 tsp. soft margarine, mayonnaise, or oil & \\
\hline vegetables & 4 & $\begin{array}{l}1 / 2 \text { cup cooked vegetables } \\
1 \text { cup raw vegetables } \\
1 / 2 \text { cup vegetable juice }\end{array}$ & $\begin{array}{l}1 \text { cup cooked or } 2 \text { cups raw bok choy, broccoli, Chinese } \\
\text { cabbage, collards, kale, mustard greens, or okra } \\
1 / 2 \text { cup calcium-fortified tomato juice }\end{array}$ \\
\hline
\end{tabular}

Note: The information in this table is from A New Food Guide for North American Vegetarians, not from the USDA MyPyramid. The number of servings and serving sizes are therefore not intended to match those from MyPyramid.

* Each serving in this column counts as a food rich in both calcium and in the other food group it resides in. For example, $1 / 4$ cup almonds counts as 1 serving of protein-rich foods and 1 serving of calcium-rich foods.

\section{Does eating a vegetarian diet reduce the risk of diseases such as heart disease and cancer?}

The appeal of vegetarian diets for many individuals lies in their potential health benefits. Research has shown that vegetarians have lower morbidity and mortality from a number of degenerative diseases, including cardiovascular disease and certain types of cancer. However, it has not yet been shown that it is the omission of meat per se that has caused these positive effects, as vegetarian diets often include an overall higher intake of fruits, vegetables, and fiber, and lower intake of total fat and saturated fat, compared with typical omnivorous diets (8). It has also been difficult to separate the beneficial effects of a vegetarian diet from those effects of commonly related lifestyle differences, such as not smoking, regular physical activity, and moderate alcohol consumption.

Consuming a vegetarian diet, or even occasional meatless meals, can make it easier for an individual to meet the Dietary Guidelines for Americans 2005 recommendation 
to consume sufficient amounts of a variety of fruits and vegetables daily, or to meet the Dietary Approaches to Stop Hypertension (DASH) recommendation to consume 4-5 servings of nuts, seeds, and dried beans per week (9). Current research also suggests that consumption of a vegan diet, in comparison with the National Cholesterol Education Program diet, may lead to better maintenance of weight loss (10). Other organizations, such as the American Institute for Cancer Research (11), the American Heart Association (12), and the National Heart, Lung, and Blood Institute (13), also recommend consuming a diet high in fruits and vegetables. Due to their dependence upon fruits, vegetables, whole grains, legumes, nuts, and seeds, well-planned vegetarian diets are more likely to meet the current recommendations for dietary fiber intake. This, in turn, helps lower the risk for chronic disease by reducing cholesterol levels and by replacing foods high in saturated fat and cholesterol with foods rich in heart-healthy monounsaturated and polyunsaturated fats.

\section{Are vegetarian diets safe for everyone?}

As with any dietary pattern, accommodations must be made for the specific nutrient needs of infants, children, adolescents, pregnant and breast-feeding women, and the elderly. As long as a conscious effort is made to choose a variety of nutritionally adequate foods, vegetarians at any age can obtain sufficient energy and nutrients necessary for health (14). Some studies, however, suggest this may be difficult for children, who may not be able to consume sufficient food to meet nutrient needs from a vegetarian or vegan diet $(15,16)$. Table 2 compares dietary recommendations for omnivorous children with those recommended for vegetarian children.

\section{Table 2. Dietary recommendations for children - omnivores and vegetarians}

\begin{tabular}{|c|c|c|c|}
\hline Food group & $\begin{array}{l}\text { MyPyramid for Kids } \\
\text { recommendations* (18) }\end{array}$ & $\begin{array}{l}\text { Recommendations for } \\
\text { vegetarian childrent (6) }\end{array}$ & $\begin{array}{l}\text { Examples of serving size } \\
\text { equivalents }\end{array}$ \\
\hline fruit & $11 / 2$ cups & 1 cup & $\begin{array}{l}1 / 2 \text { cup equivalent of fruit: } \\
1 / 2 \text { cup fresh, frozen, or canned fruit } \\
1 / 4 \text { cup dried fruit } \\
1 \text { medium whole fruit } \\
1 / 2 \text { cup fruit juice }\end{array}$ \\
\hline grains & $60 z$ & $6 \mathrm{oz}$ & $\begin{array}{l}1 \text { oz equivalent of grains: } \\
1 \text { slice bread } \\
\sim 1 \text { cup dry cereal (depends on brand) } \\
1 / 2 \text { cup cooked rice, pasta, or cereal }\end{array}$ \\
\hline $\begin{array}{l}\text { meat and } \\
\text { beans }\end{array}$ & $50 z$ & $6 o z$ & $\begin{array}{l}1 \text { oz equivalent of meat/beans: } \\
1 / 4 \text { cup cooked dry beans, lentils, peas } \\
1 \text { egg } \\
1 / 2 \text { oz nuts or seeds } \\
1 \text { Tbsp nut or seed butter }\end{array}$ \\
\hline milk & 3 cups & $\ddagger$ & $\begin{array}{l}1 \text { cup equivalent of milk: } \\
11 / 2 \text { oz natural cheese } \\
2 \text { oz processed cheese } \\
1 \text { cup milk } \\
1 \text { cup yogurt }\end{array}$ \\
\hline oils & 5 tsp & 2 tsp & $\begin{array}{l}1 \text { tsp equivalent of oils: } \\
1 \text { tsp soft margarine } \\
1 \text { Tbsp low-fat mayonnaise } \\
1 \text { tsp vegetable oil } \\
2 \text { Tbsp low-fat salad dressing }\end{array}$ \\
\hline vegetables & $21 / 2$ cups & 4 cups & $\begin{array}{l}1 / 2 \text { cup equivalent of vegetables: } \\
1 / 2 \text { cup chopped raw or cooked vegetable } \\
1 \text { cup raw leafy vegetable } \\
1 / 2 \text { cup vegetable juice }\end{array}$ \\
\hline $\begin{array}{l}\text { Notes: } \\
\text { * For an } 1800 \text {-ca } \\
\text { † For children } 9 \text { - } \\
\text { † It is recommen } \\
\text { (see table } 1 \text { for e } \\
\text { breakfast cereal }\end{array}$ & $\begin{array}{l}\text { liet. } \\
\text { ars of age. Additional foods can } \\
\text { lat of the foods consumed daily } \\
\text { les) and } 2 \text { servings should com } \\
\text { ed with vitamin } B_{12}, 1 \text { cup of } \mathrm{m}\end{array}$ & $\begin{array}{l}\text { chosen to meet energy needs. } \\
\text { vegetarian children, } 10 \text { serving } \\
\text { m foods rich in vitamin } B_{12} \text {. Ex } \\
\text { r } 1 \text { cup of yogurt. }\end{array}$ & $\begin{array}{l}\text { ould come from calcium-rich foods } \\
\text { les of the latter include } 1 \text { cup of }\end{array}$ \\
\hline
\end{tabular}




\section{Is it important to combine amino acid food sources in order to receive a sufficient quality of protein in the diet?}

Yes, it is important to combine amino acid food sources because plant proteins other than soy are low in one or more of the essential amino acids. However, having adequate protein quality is easily accomplished by eating a variety of foods. Examples of vegetarian meals containing all the essential amino acids include a peanut butter sandwich; beans and rice; meals containing tofu or tempeh; meals containing eggs; and meals containing dairy products. Furthermore, there is no need to be sure that every meal or snack has the complete list of essential amino acids; it suffices to eat them over the course of a day (3).

\section{What is a nutritionally adequate vegetarian diet?}

To be nutritionally adequate, any dietary pattern-vegetarian or otherwise-should provide balance, variety, and moderation. Table 1 provides recommendations for adults (18 years of age and older) following a vegetarian diet. Suggested dietary patterns for children, adolescents, pregnant and lactating women (6), and vegans (17) are available elsewhere (see references 6 and 17 for examples).

\section{REFERENCES}

1. Key, T. J., P. N. Appleby, and M. S. Rosell. 2006. Health effects of vegetarian and vegan diets. Proc Nutr Soc 65:35-41.

2. Baines, S., J. Powers, and W. J. Brown. 2007. How does the health and wellbeing of young Australian vegetarian and semi-vegetarian women compare with non-vegetarians? Public Health Nutr 10:436-442.

3. USDA (United States Department of Agriculture). 2008. Tips and resources: Vegetarian diets. MyPyramid.gov Web site, http://mypyramid.gov/tips_resources/ vegetarian_diets.html.

4. Karabudak, E., G. Kiziltan, and N. Cigerim. 2008. A comparison of some of the cardiovascular risk factors in vegetarian and omnivorous Turkish females. J Hum Nutr Diet 21:13-22.

5. Kornsteiner, M., I. Singer, and I. Elmadfa. 2008. Very low n-3 long-chain polyunsaturated fatty acid status in Austrian vegetarians and vegans. Ann Nutr Metab 52:37-47.

6. Messina, V., V. Melina, and A. R. Mangels. 2003. A new food guide for North American vegetarians. J Am Diet Assoc 103:771-775.

7. Mayo Clinic. 2008. Food Pyramid: An option for better eating. Mayo Clinic Web site, http://www.mayoclinic.com/health/healthy-diet/NU00190.

8. Chang-Claude, J., S. Hermann, U. Eilber, and K. Steindorf. 2005. Lifestyle determinants and mortality in German vegetarians and health-conscious persons: Results of a 21-year follow-up. Cancer Epidemiol Biomarkers Prev 14:963-968.

9. U.S. Department of Health and Human Services. 2005. Dietary Guidelines for Americans Web site, http://www.health.gov/DietaryGuidelines/. 
10. Turner-McGrievy, G. M., N. D. Barnard, and A. R. Scialli. 2007. A two-year randomized weight loss trial comparing a vegan diet to a more moderate low-fat diet. Obesity (Silver Spring) 15:2276-2281.

11. World Cancer Research Fund. 2007. Food, nutrition, physical activity, and the prevention of cancer: A global perspective. Washington, DC: American Institute for Cancer Research.

12. Lichtenstein, A. H., L. J. Appel, M. Brands, M. Carnethon, S. Daniels, H. A. Franch, B. Franklin, P. Kris-Etherton, W. S. Harris, B. Howard, N. Karanja, M. Lefevre, L. Rudel, F. Sacks, L. Van Horn, M. Winston, and J. Wylie-Rosett. 2006. Diet and lifestyle recommendations revision 2006: A scientific statement from the American Heart Association Nutrition Committee. Circulation 114:82-96.

13. U. S. Department of Health and Human Services; National Institutes of Health; and National Heart Lung and Blood Institute. 2003. JNC 7 express: The seventh report of the Joint National Committee on prevention, detection, evaluation, and treatment of high blood pressure. Maryland: National Institutes of Health.

14. American Dietetic Association and Dietitians of Canada. 2003. Position of the American Dietetic Association and Dietitians of Canada: Vegetarian diets. J Am Diet Assoc 103:748-765.

15. Ambroszkiewicz, J., W. Klemarczyk, M. Chelchowska, J. Gajewska, and T. Laskowska-Klita. 2006. Serum homocysteine, folate, vitamin B12 and total antioxidant status in vegetarian children. Adv Med Sci 51:265-268.

16. Ambroszkiewicz, J., W. Klemarczyk, J. Gajewska, M. Chelchowska, and T. Laskowska-Klita. 2007. Serum concentration of biochemical bone turnover markers in vegetarian children. Adv Med Sci 52:279-282.

17. Venti, C. A., and C. S. Johnston. 2002. Modified food guide pyramid for lactovegetarians and vegans. J Nutr 132:1050-1054.

18. USDA (United States Department of Agriculture). 2008. MyPyramid for Kids. MyPyramid.gov Web site, http://mypyramid.gov/kids/.

\section{METRIC CONVERSIONS}

\begin{tabular}{|l|c|c|c|}
\hline English & $\begin{array}{c}\text { Conversion factor for } \\
\text { English to metric }\end{array}$ & $\begin{array}{c}\text { Conversion factor for } \\
\text { metric to English }\end{array}$ & Metric \\
\hline teaspoon (tsp) & 4.93 & 0.20 & milliliter (ml) \\
\hline tablespoon (tbsp) & 14.79 & 0.067 & milliliter (ml) \\
\hline ounce (oz) & 28.35 & 0.035 & gram (g) \\
\hline cup & 236.6 & 0.004 & milliliter (ml) \\
\hline
\end{tabular}




\section{FOR FURTHER INFORMATION}

To order or obtain printed ANR publications and other products, visit the ANR Communication Services online catalog at http://anrcatalog.ucdavis.edu. You can also place orders by mail, phone, or FAX, or request a printed catalog of our products from:

University of California

Agriculture and Natural Resources

Communication Services

6701 San Pablo Avenue, 2nd Floor

Oakland, California 94608-1239

Telephone: (800) 994-8849 or (510) 642-2431

FAX: (510) 643-5470

E-mail inquiries: danrcs@ucdavis.edu

(C) 2008 The Regents of the University of California

Division of Agriculture and Natural Resources

All rights reserved.

No part of this publication may be reproduced, stored in a retrieval system, or transmitted, in any form or by any means, electronic, mechanical, photocopying, recording, or otherwise, without the written permission of the publisher and the authors.

Publication 8373

ISBN-13: 978-1-60107-645-8

Production of this material was supported by a grant from the Vitamin Cases Consumer Settlement Fund, created as a result of an antitrust class action. One of the purposes of the fund is to improve the health and nutrition of California consumers.

The University of California prohibits discrimination or harassment of any person on the basis of race, color, national origin, religion, sex, gender identity, pregnancy (including childbirth, and medical conditions related to pregnancy or childbirth), physical or mental disability, medical condition (cancer-related or genetic characteristics), ancestry, marital status, age, sexual orientation, citizenship, or service in the uniformed services (as defined by the Uniformed Services Employment and Reemployment Rights Act of 1994: service in the uniformed services includes membership, application for membership, performance of service, application for service, or obligation for service in the uniformed services) in any of its programs or activities.

University policy also prohibits reprisal or retaliation against any person in any of its programs or activities for making a complaint of discrimination or sexual harassment or for using or participating in the investigation or resolution process of any such complaint.

University policy is intended to be consistent with the provisions of applicable State and Federal laws.

Inquiries regarding the University's nondiscrimination policies may be directed to the Affirmative Action/Equal Opportunity Director, University of California, Agriculture and Natural Resources, 1111 Franklin Street, 6 6 th Floor, Oakland, CA 94607, (510) 987-0096. For information about ordering this publication, telephone 1-800-994-8849. For assistance in downloading this publication, telephone 530-754-3927.

An electronic copy of this publication can be found at the ANR Communication Services catalog Web site, http://anrcatalog.ucdavis.edu.

This publication has been anonymously peer reviewed for technical accuracy by University of California scientists and other qualified professionals. This review process was managed by the ANR Associate Editor for Food and Nutrition.

pr-06/09-LR/CR 